\title{
Analysis of Energy Cost Savings by Substituting Heavy Fuel Oil with Alternative Fuel for a Pozzolana Dryer Case Study of Bamburi Cement
}

\author{
Veronica Kavila Ngunzi \\ Department of Engineering and Innovative Technology, Kisii University, Kisii, Kenya \\ Email address: \\ vngunzi@yahoo.com
}

\section{To cite this article:}

Veronica Kavila Ngunzi. Analysis of Energy Cost Savings by Substituting Heavy Fuel Oil with Alternative Fuel for a Pozzolana Dryer. Case Study of Bamburi Cement. American Journal of Energy Engineering. Vol. 3, No. 6, 2015, pp. 93-102. doi: 10.11648/j.ajee.20150306.13

\begin{abstract}
The research study was carried out with the aim of analyzing the energy cost saving achieved by substituting heavy fuel oil with alternative fuel for a pozzolana dryer. This was carried out on an existing dryer where data from reports for previous years on energy requirements, that is, heavy fuel oil cost and usage was collected. An auxiliary system to handle biomass was designed and fabricated. Further a projected substitution scenario was determined through the use of excel worksheet which was set as the benchmark of evaluation on the expectations of the actual substitution. Comparison of fuel composition and cost of both actual and projected substitution scenarios was carried out. Further an economic analysis was carried out to establish the viability of the project. From the study findings of both the projected and actual substitution, the cost of energy was reducing with an increase in alternative fuel substitution with coefficients of correlation $\left(\mathrm{R}^{2}\right)$ of 1 and 0.5422 respectively. Again the projected and actual savings were increasing with an increase in alternative fuel substitution with coefficients of correlation $\left(\mathrm{R}^{2}\right)$ of 1 and 0.6288 respectively. From the economic analysis, the cost benefit analysis gave a positive net present value of $67,409,041$. IRR was $4.10 \%$, simple payback period was 12 days and return on investment was $29.72 \%$. Using these four techniques of capital budgeting, the investment was worthwhile to undertake. Further on economic analysis substitution effect was carried out. On the substitution effect, there was gradual cost drop of the energy used to dry pozzolana from 357491491 Kenya shillings with increasing percentage alternative fuel substituted to 106,269975 Kenya shillings when heavy fuel oil is completely substituted by alternative fuel. From the study, the high and fluctuating cost of heavy fuel oil used in pozzolana drying can be achieved through substitution with alternative fuel.
\end{abstract}

Keywords: Heavy Fuel Oil, Alternative Fuel, Projected Substitution, Actual Substitution, Existing Dryer, Auxiliary System

\section{Introduction}

There has been overreliance on fossil fuels in many manufacturing industries over the years. This has led to evident increase in cost of fuel and increasing production cost. The cost increase is caused by hidden costs which are not paid for by the companies that produce and sell energy but are passed on to the consumers of the energy. These costs include climate change adaptation costs, climate change damage costs, and fossil fuel dependence costs. These costs are indirect and difficult to determine, therefore they have traditionally remained external to the energy pricing system, and are thus often referred to as externalities. Hence the overreliance on fossil fuels results in damage to human health, the environment, and the economy. (www.ucsusa.org,
19.09.2013). Again the fossil fuels being relied on for industrial energy supply will most probably be depleted within a few hundred years.

With the growing realization of the impact of fossil fuels on global warming, there is a renewed interest in the utilization of biomass as a renewable and carbon-neutral energy source. The use of biomass and waste fuels is a growing area based on sound economic and environmental benefits. Biomass fuel-switching is possible, achievable and beneficial to the environment and companies that are willing to embrace it. Once implemented, companies can also benefit from the generation of carbon credits through the Clean Development Mechanism (United Nations Development Programme, 2009).

The production of cement is also an energy-intensive process. The typical energy consumption of a modern cement 
plant is about $110-120 \mathrm{kWh}$ per ton of produced cement (Alsop, 2001). The energy consumption in the cement mills contributes roughly $50 \mathrm{~kg} \mathrm{CO}$ emissions per tonne to the overall greenhouse gas emissions of the industry (MIT Research, 2011). The most energy-consuming cement manufacturing process is finish grinding drawing on average $40 \%$ of the total energy required to produce a ton of cement (Alsop, 2001).

The cement manufacturing industry is therefore under increasing pressure to reduce emissions. Cement manufacturing releases a lot of emissions such as carbon dioxide $\left(\mathrm{CO}_{2}\right)$ and nitrogen oxide (NOx). It is estimated that 5 percent of global carbon dioxide emissions originate from cement production (Hendriks, et al, 1998). The use of alternative fuels in cement manufacturing, therefore do not only afford considerable energy cost reduction, but they also have significant ecological benefits of conserving nonrenewable resources, the reduction of waste disposal requirements and reduction of emissions. Use of low-grade alternative fuels in some kiln systems reduces NOx emissions due to re-burn reactions. There is an increased net global reduction in $\mathrm{CO}_{2}$ emissions when waste is combusted in the cement kiln systems as opposed to dedicated incinerators.

Pozzolana is one of the main components of pozzolanic cement accounting for $35 \%$ of the mass of cement. This pozzolana has to be dried before inter-grinding with clinker in order to maintain cement to clinker ratio and to maintain higher grinding efficiency. The drying process uses a couple of dryers which are traditionally equipped with hot gas generators (HGG) fired by either diesel oil or heavy fuel oil (HFO). This increases the energy per tonne of cement produced. This is due to the energy required to reduce the moisture content to about two to three percent. However heavy fuel oil is facing high and fluctuating cost and the price gap between the fossil fuels in use today to dry pozzolana and the possible price of the biomass is in the range 8 - 10€/GJ (Bamburi Cement Annual Report, 2012). Therefore, there is a clear interest to study the possibility of converting the existing HGGs to use biomass in order to reduce cost of fuel for drying pozzolana and dependence on and the use of fossil fuels. Currently the use of biomass instead of fossil fuel is gaining acceptance as a cost effective form of renewable energy. Beside the lower costs, biomass fuel results in lower emissions and residues.

According to Kurchania et al.(2006), biomass energy or "bio-energy" includes any solid, liquid or gaseous fuel, or any electric power or useful chemical product derived from organic matter, whether directly from plants or indirectly from plant-derived industrial, commercial or urban wastes, or agricultural and forestry residues. Thus bio-energy can be derived from a wide range of raw materials and produced in a variety of ways. Because of the wide range of potential feed stocks and the variety of technologies to produce them and process them, bio-energy is usually considered as a series of many different feedstock/technology combinations.

Previous studies carried out to address this concern have aimed at reducing $\mathrm{CO}^{2}$ emission by substitution and focused on price elasticity of the inter-fuel substitution using mathematical models. The previous studies have used data obtained from entire production process involved in cement manufacturing industries. This however faces the challenge of generalization given that the different operational areas of the manufacturing system for cement are likely to have different energy consumption patterns and requirements. There is however a need to apply the lessons learned from the studies using the mathematical models to study the interfuel substitution in specific operational areas of the cement manufacturing sectors that consume large quantities of fossil fuels and observe the behavior of the different processes. Such an observation can be done when an experiment is designed to assess the variation in energy cost behavior at different levels when the fossil fuels are substituted with alternative fuels. At the cement grinding stage of the process, it is possible to carry out this substitution since pozzolana drying falls in this category of sectors that consumes large quantities of fossil fuels. The stage is also recognized as an important source of $\mathrm{CO}_{2}$ emissions.

Substantial potential for energy efficiency improvement exists in the pozzolana drying. a portion of this potential can be achieved as part of modification and expansion of existing facilities. At Bamburi Cement Limited Nairobi grinding plant, an opportunity exists where pozzolana dryer can be modified to accommodate biomass for substitution. This is because biomass is the most cost-effective and practical and therefore offers the most realistic and sustainable energy strategy. This study analyses the energy cost savings by substituting heavy fuel oil with biomass for a pozzolana dryer in order to achieve sustainable energy strategy by improving the existing dryer to accommodate the use of alternative fuels.

\section{Materials and Methods}

\subsection{Description of the Experiment Site}

The dryer studied is at the Nairobi Grinding Plant (NGP) in Athi-river about $26 \mathrm{~km}$ from Nairobi along the old Mombasa road and next to the Namanga junction. This plant is part of the Bamburi Cement Company which belongs to the Lafarge Group (the world largest manufacturer of building materials). On average the plant produces 100, 000 tonnes of cement consuming about 150, 000 litres of HFO per month. The HFO is used in drying pozzolana before inter-grinding with the clinker.

\subsection{Description of Cement Drying Process}

Figure 1 below shows the cement drying process. The existing pozzolana dryer installation basically consists of HGG fired with HFO and waste oil drum dryer, filter and exhaust fan. HFO is transferred to the air-fuel mixing chamber of the burner. LPG is also introduced in the mixing chamber to improve the ignition of the fuel. Atomizing compressed air at $31^{\circ} \mathrm{C}$ is introduced to the atomizing unit where it meets primary and secondary air. Atomized air and 
fuel then mix and ignition and combustion take place while flue gases are generated. The dryer slopes slightly so that the discharge end is lower than the material feed end in order to convey the material through the dryer under gravity. Material to be dried enters the dryer, and as the dryer rotates, the material is lifted up by a series of internal fins lining the inner wall of the dryer. When the material gets high enough to roll back off the fins, it falls back down to the bottom of the dryer, passing through the hot gas stream as it falls. This gas stream is moving towards the discharge end from the feed end (known as co-current flow) by help of a suction fan. The gas stream is made up of a mixture of air and combustion gases from a burner, in which case the dryer is called a direct heated dryer. Wet gypsum and pozzolana are dried then conveyed through conveyor and elevator system to their storage silos.

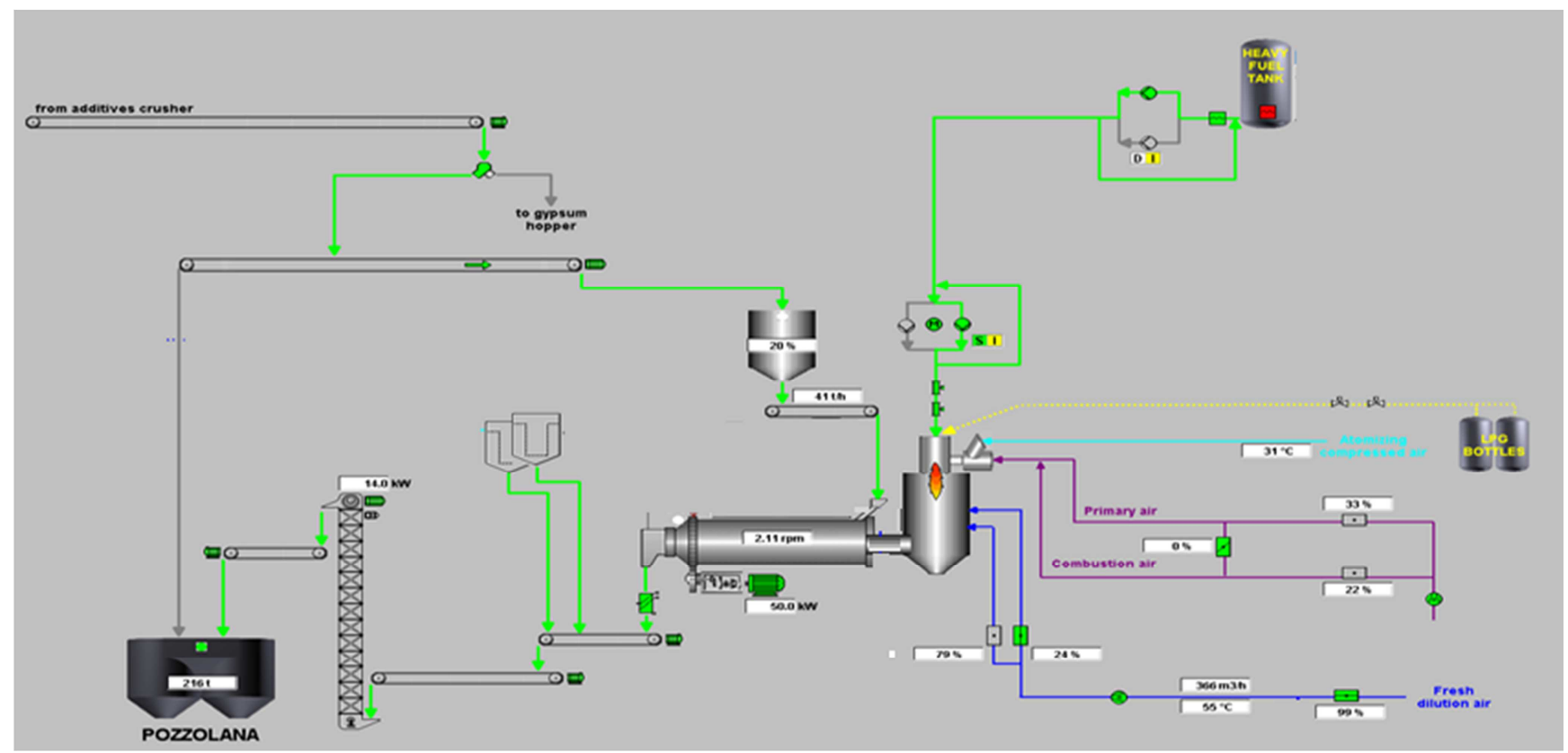

Figure 1. Cement Drying Process.

\subsection{Description of the Pilot Auxiliary System to Handle Biomass}

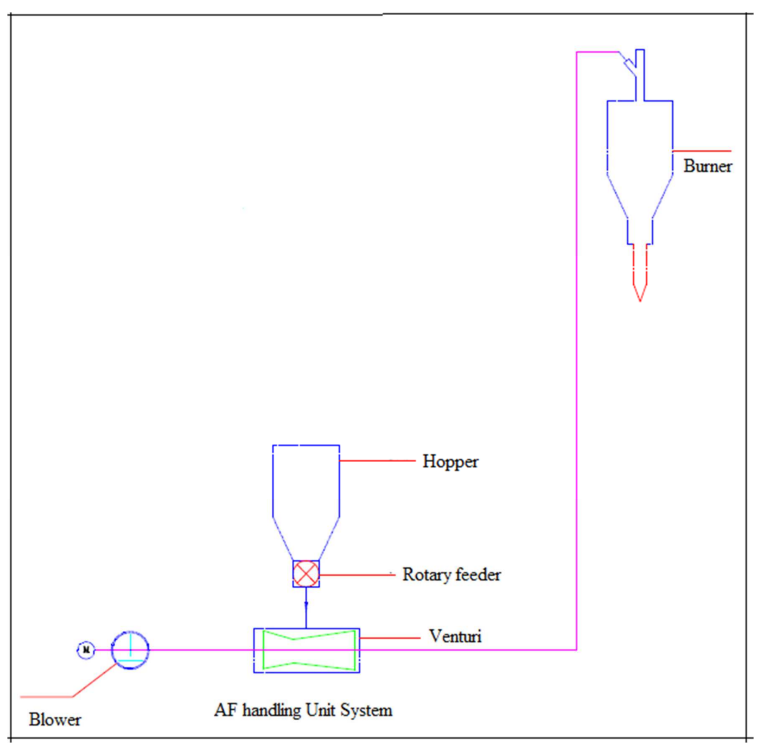

Figure 2. Auxiliary System.

An auxiliary system was designed and fabricated to handle and deliver the AF fuel. It consisted of a blower run by a $30 \mathrm{~kW}$ motor, venturi, rotary feeder run by a $20 \mathrm{~kW}$ motor, a hopper of 2 tonne capacity and piping system with a diameter of $150 \mathrm{~mm}$ to the burner. The blower through centrifugal force propels air forward giving it some velocity. When the air reaches the venturi there is a pressure drop and increase of velocity of the air. At the same time rice husks flow down the hopper and discharged through the rotary feeder. They are then blown though the piping system into the burner where they are mixed with HFO. The rice husks are introduced at various percentages of substitution and data. The line presentation of the auxiliary system is as shown in figure 2 .

\subsection{Data Acquisition}

Data was collected for a period of 20 days where GJ of HFO and AF used for a number of hours of running the dryer for different percentages of substitution were obtained. This data was analyzed to get the total cost of HFO, AF and energy per year which was presented inform of graphs. Again a projected substitution scenario was carried out for the purposes of comparison and drawing of conclusion on the viability of this project.

The procedure below was carried out for the year 2014 .

Given;

i. $\mathrm{HFO}$ price $\mathrm{Kes} / \mathrm{kl}=76599.79=\mathrm{A}$

$\mathrm{HFO}$ density ton $/ \mathrm{kl}=0.92=\mathrm{B}$

HFO LHV GJ/ton $=39.77=\mathrm{C}$

Therefore;

$\mathrm{HFO} \mathrm{Kes} / \mathrm{GJ}=\frac{A \div B}{C}=D$ 


$$
\frac{76,599.79 \div 0.92}{39.79}=2,093.47
$$

ii. Assuming $1 €=116 \mathrm{Kes}$

Therefore HFO $€ / G J=\frac{D}{116}=\frac{2093.47}{116}=18.05=\mathrm{E}$

iii. Budget MJ $/ \mathrm{t}$ Cement $=125=\mathrm{F}$

Budget ton of cement in $2014=1366120.6=\mathrm{G}$

Budget $\mathrm{GJ} / \mathrm{Yr}=\frac{F \times G}{1000}=\frac{125 \times 1366120.0}{1000}=170765.08=\mathrm{I}$

iv. Assuming there was additional cost of labour to handle alternative fuel at $12 \%$

Alternative fuel $\mathrm{LHV} \mathrm{GJ} / \mathrm{t}=12.70$

Alternative fuel $€ / G J=(1+12 \%) \times(4.39+0.4)=5.36$

Where $4.39=$ cost of rice husks per Giga joule

$0.4=$ cost of bags per giga joule

Alternative fuel kes $/ \mathrm{GJ}=5.36 \times 116=622.32$

Where

$1 €=116$ kes. v. Therefore

$$
\text { HFO Cost }=I \times(1-\% A F) \times E
$$

Where;

$\mathrm{I}$ = budget $\mathrm{GJ} / \mathrm{yr}$

$\mathrm{E}=\mathrm{HFO} \mathrm{kes} / \mathrm{GJ}$

AF fuel cost $=($ Budget GJ/yr x AF substitution \%) $\times$ AF cost in Kes/ GJ

(Source of Costs - NGP annual Report, 2012)

\section{Results and Discussion}

\subsection{Projected Substitution Scenario}

The projected substitution scenarios were calculated using excel program and tabulated as shown shown in table 1 below.

Table 1. Projected Substitution Scenarios

\begin{tabular}{lllllll}
\hline DESCRIPTION & $\mathbf{0 \%}$ & $\mathbf{5 \%}$ & $\mathbf{1 0} \%$ & $\mathbf{1 5 \%}$ & $\mathbf{2 0 \%}$ \\
\hline HFO Cost (Kes) & $357,491,491.33$ & $339,616,916.77$ & $321,742,342.20$ & $303,867,767.63$ & $285,993,193.07$ & $268,118,618.50$ \\
AF Cost (Kes) & - & $5,313,498.75$ & $10,626,997.50$ & $15,940,496.25$ & $21,253,995.01$ \\
Total Cost (Kes) & $357,491,491.33$ & $344,930,415.52$ & $332,369,339.70$ & $319,808,263.89$ & $307,247,188.07$ \\
Savings (Kes) & - & $12,561,075.82$ & $25,122,151.63$ & $37,683,227.45$ & $50,244,303.26$ & $62,805,379.08$ \\
\hline
\end{tabular}

\subsection{Actual Substitution Scenarios}

An actual test of the substitution was carried out at various percentages for twenty days to establish GJ of HFO and AF used. The data was further analyzed to establish the amount of energy used per day per hour and per year and tabulated in table 2 below.

\begin{tabular}{|c|c|c|c|c|c|c|c|c|c|c|}
\hline Day & 1 & 2 & 3 & 4 & 5 & 6 & 7 & 8 & 9 & 10 \\
\hline$\%$ substitution & 0.00 & 1.26 & 3.74 & 4.15 & 5.18 & 5.95 & 6.76 & 7.70 & 8.02 & 9.55 \\
\hline GJ of HFO Used & 425.87 & 515.80 & 628.28 & 468.05 & 286.26 & 648.70 & 573.73 & 587.74 & 504.75 & 543.27 \\
\hline GJ of AF used & 0.00 & 7.01 & 18.80 & 19.30 & 22.91 & 41.02 & 47.54 & 57.49 & 54.31 & 64.25 \\
\hline Total GJ & 425.87 & 522.81 & 647.08 & 487.35 & 309.17 & 689.72 & 621.27 & 645.23 & 559.06 & 607.52 \\
\hline $\begin{array}{l}\text { Hours of running } \\
\text { dryer }\end{array}$ & 11.85 & 14.78 & 19.12 & 15.98 & 10.22 & 22.92 & 20.52 & 21.72 & 18.75 & 21.00 \\
\hline $\mathrm{GJ} / \mathrm{hr}$ of $\mathrm{HFO}$ & 35.94 & 34.90 & 32.86 & 29.29 & 28.01 & 28.30 & 27.96 & 27.06 & 26.92 & 25.87 \\
\hline $\mathrm{GJ} / \mathrm{hr}$ of $\mathrm{AF}$ & 0.00 & 0.47 & 0.98 & 1.21 & 2.24 & 1.79 & 2.32 & 2.65 & 2.90 & 3.06 \\
\hline Total GJ/hr & 35.94 & 35.37 & 33.84 & 30.50 & 30.25 & 30.09 & 30.28 & 29.71 & 29.82 & 28.93 \\
\hline GJ/day of HFO & 862.52 & 837.56 & 788.64 & 702.95 & 672.23 & 679.27 & 671.03 & 649.44 & 646.08 & 620.88 \\
\hline $\mathrm{GJ} /$ day of $\mathrm{AF}$ & 0.00 & 11.38 & 23.60 & 28.99 & 53.80 & 42.95 & 55.60 & 63.52 & 69.52 & 73.43 \\
\hline Total GJ/day & 862.52 & 848.95 & 812.23 & 731.94 & 726.04 & 722.22 & 726.63 & 712.96 & 715.60 & 694.31 \\
\hline GJ/year of HFO & 314820.35 & 305710.96 & 287852.13 & 256578.10 & 245365.71 & 247932.46 & 244925.67 & 237044.31 & 235819.20 & 226621.20 \\
\hline $\mathrm{GJ} /$ year of $\mathrm{AF}$ & 0.00 & 4154.78 & 8613.39 & 10579.97 & 19637.14 & 15677.80 & 20294.85 & 23186.57 & 25373.63 & 26801.43 \\
\hline Total GJ/Yr & 314820.35 & 309865.74 & 296465.52 & 267158.07 & 265002.86 & 263610.26 & 265220.53 & 260230.88 & 261192.83 & 253422.63 \\
\hline Cost of HFO/Year & $\begin{array}{l}658919001.8 \\
2\end{array}$ & $\begin{array}{l}639853040 . \\
87\end{array}$ & $\begin{array}{l}602474516 . \\
23\end{array}$ & $\begin{array}{l}537017958 . \\
32\end{array}$ & $\begin{array}{l}513550440 . \\
00\end{array}$ & $\begin{array}{l}518922640 . \\
31\end{array}$ & $\begin{array}{l}512629432 . \\
57\end{array}$ & $\begin{array}{l}496133739 . \\
56\end{array}$ & $\begin{array}{l}493569585 . \\
60\end{array}$ & $\begin{array}{l}474318171 \\
.60\end{array}$ \\
\hline Cost of AF/Year & 0.00 & 2584271.12 & 5357528.03 & 6580744.43 & $\begin{array}{l}12214302.8 \\
6\end{array}$ & 9751592.25 & $\begin{array}{l}12623399.0 \\
6\end{array}$ & $\begin{array}{l}14422049.3 \\
9\end{array}$ & $\begin{array}{l}15782399.1 \\
0\end{array}$ & $\begin{array}{l}16670488 . \\
57\end{array}$ \\
\hline $\begin{array}{l}\text { Total of energy Cost } \\
\text { /year }\end{array}$ & $\begin{array}{l}658919001.8 \\
2\end{array}$ & $\begin{array}{l}642437311 . \\
99\end{array}$ & $\begin{array}{l}607832044 . \\
27\end{array}$ & $\begin{array}{l}543598702 . \\
75\end{array}$ & $\begin{array}{l}525764742 . \\
86\end{array}$ & $\begin{array}{l}528674232 . \\
57\end{array}$ & $\begin{array}{l}525252831 \\
64\end{array}$ & $\begin{array}{l}510555788 . \\
95\end{array}$ & $\begin{array}{l}509351984 . \\
70\end{array}$ & $\begin{array}{l}490988660 \\
.17\end{array}$ \\
\hline $\begin{array}{l}\text { Cost savings (kes) / } \\
\text { year }\end{array}$ & 0.00 & $\begin{array}{l}16481689.8 \\
3\end{array}$ & $\begin{array}{l}51086957.5 \\
5\end{array}$ & $\begin{array}{l}115320299 . \\
07\end{array}$ & $\begin{array}{l}133154258 . \\
96\end{array}$ & $\begin{array}{l}130244769 . \\
25\end{array}$ & $\begin{array}{l}133666170 . \\
18\end{array}$ & $\begin{array}{l}148363212 . \\
87\end{array}$ & $\begin{array}{l}149567017 . \\
12\end{array}$ & $\begin{array}{l}167930341 \\
.65\end{array}$ \\
\hline $\begin{array}{l}\text { Cost savings (euro) } \\
\text { / year }\end{array}$ & 0.00 & 138501.60 & 429302.16 & 969078.14 & 1118943.35 & 1094493.86 & 1123245.13 & 1246749.69 & 1256865.69 & 1411179.34 \\
\hline
\end{tabular}

Table 2. Actual Substitution Data. 


\begin{tabular}{|c|c|c|c|c|c|c|c|c|c|c|}
\hline Day & 11 & 12 & 13 & 14 & 15 & 16 & 17 & 18 & 19 & 20 \\
\hline \%substitution & 10.81 & 11.69 & 12.86 & 13.49 & 14.51 & 15.87 & 16.12 & 20.17 & 20.60 & 21.28 \\
\hline GJ of HFO Used & 612.12 & 540.87 & 480.04 & 468.13 & 623.09 & 348.48 & 576.22 & 450.79 & 210.61 & 501.35 \\
\hline GJ of AF used & 72.15 & 71.56 & 71.56 & 73.03 & 105.74 & 133.78 & 110.71 & 113.93 & 68.61 & 135.53 \\
\hline Total GJ & 684.27 & 612.43 & 551.60 & 541.16 & 728.83 & 482.26 & 686.93 & 564.72 & 279.22 & 636.88 \\
\hline $\begin{array}{l}\text { Hours of running } \\
\text { dryer }\end{array}$ & 24.00 & 22.12 & 18.88 & 17.93 & 22.32 & 14.88 & 20.82 & 18.75 & 8.93 & 20.25 \\
\hline $\mathrm{GJ} / \mathrm{hr}$ of $\mathrm{HFO}$ & 25.51 & 24.45 & 25.43 & 26.11 & 27.92 & 23.42 & 27.68 & 24.04 & 23.58 & 24.76 \\
\hline $\mathrm{GJ} / \mathrm{hr}$ of $\mathrm{AF}$ & 3.01 & 3.24 & 3.79 & 4.07 & 4.74 & 8.99 & 5.32 & 6.08 & 7.68 & 6.69 \\
\hline Total GJ/hr & 28.51 & 27.69 & 29.22 & 30.18 & 32.65 & 32.41 & 32.99 & 30.12 & 31.27 & 31.45 \\
\hline GJ/day of HFO & 612.12 & 586.84 & 610.22 & 626.61 & 669.99 & 562.06 & 664.23 & 577.01 & 566.03 & 594.19 \\
\hline $\mathrm{GJ} /$ day of $\mathrm{AF}$ & 72.15 & 77.64 & 90.97 & 97.75 & 113.70 & 215.77 & 127.62 & 145.83 & 184.39 & 160.63 \\
\hline Total GJ/day & 684.27 & 664.48 & 701.19 & 724.36 & 783.69 & 777.84 & 791.85 & 722.84 & 750.42 & 754.82 \\
\hline GJ/year of HFO & 223423.80 & 214196.26 & 222730.42 & 228712.70 & 244546.08 & 205153.55 & 242444.15 & 210609.09 & 206600.63 & 216880.30 \\
\hline $\mathrm{GJ} /$ year of $\mathrm{AF}$ & 26334.75 & 28339.31 & 33202.63 & 35680.02 & 41500.11 & 78757.58 & 46581.15 & 53228.10 & 67303.87 & 58629.27 \\
\hline Total GJ/Yr & 249758.55 & 242535.57 & 255933.05 & 264392.73 & 286046.18 & 283911.13 & 289025.30 & 263837.18 & 273904.50 & 275509.57 \\
\hline Cost of & 467626013.4 & 448312765.4 & 466174776.8 & 478695691 & 511834935.5 & 429386376.7 & 507435605 & 440804821 & 432415112 & 45393046 \\
\hline HFO/Year & 0 & 4 & 6 & .49 & 4 & 7 & .65 & .18 & .52 & 0.15 \\
\hline Cost of AF/Year & 16380214.50 & 17627052.59 & 20652034.07 & $\begin{array}{l}22192973 . \\
88\end{array}$ & 25813066.88 & 48987215.16 & $\begin{array}{l}28973477 . \\
00\end{array}$ & $\begin{array}{l}33107875 . \\
71\end{array}$ & $\begin{array}{l}41863009 . \\
99\end{array}$ & $\begin{array}{l}36467408 . \\
47\end{array}$ \\
\hline Total of energy & 484006227.9 & 465939818.0 & 486826810.9 & 500888665 & 537648002.4 & 478373591.9 & 536409082 & 473912696 & 474278122 & 49039786 \\
\hline Cost /year & 0 & 3 & 3 & .37 & 2 & 4 & .65 & .90 & .51 & 8.62 \\
\hline Cost savings & 174912773.9 & 192979183.7 & 172092190.8 & 158030336 & 121270999.4 & 180545409.8 & 122509919 & 185006304 & 184640879 & 16852113 \\
\hline (kes) / year & 2 & 9 & 9 & .45 & 0 & 8 & .17 & .92 & .31 & 3.20 \\
\hline $\begin{array}{l}\text { Cost savings } \\
\text { (euro) / year }\end{array}$ & 1469855.24 & 1621673.81 & 1446152.86 & $\begin{array}{l}1327986.0 \\
2\end{array}$ & 1019084.03 & 1517188.32 & $\begin{array}{l}1029495.1 \\
2\end{array}$ & $\begin{array}{l}1554674.8 \\
3\end{array}$ & $\begin{array}{l}1551604.0 \\
3\end{array}$ & $\begin{array}{l}1416143.9 \\
8\end{array}$ \\
\hline
\end{tabular}

\subsection{Projected and Actual Total Energy Cost per Year}

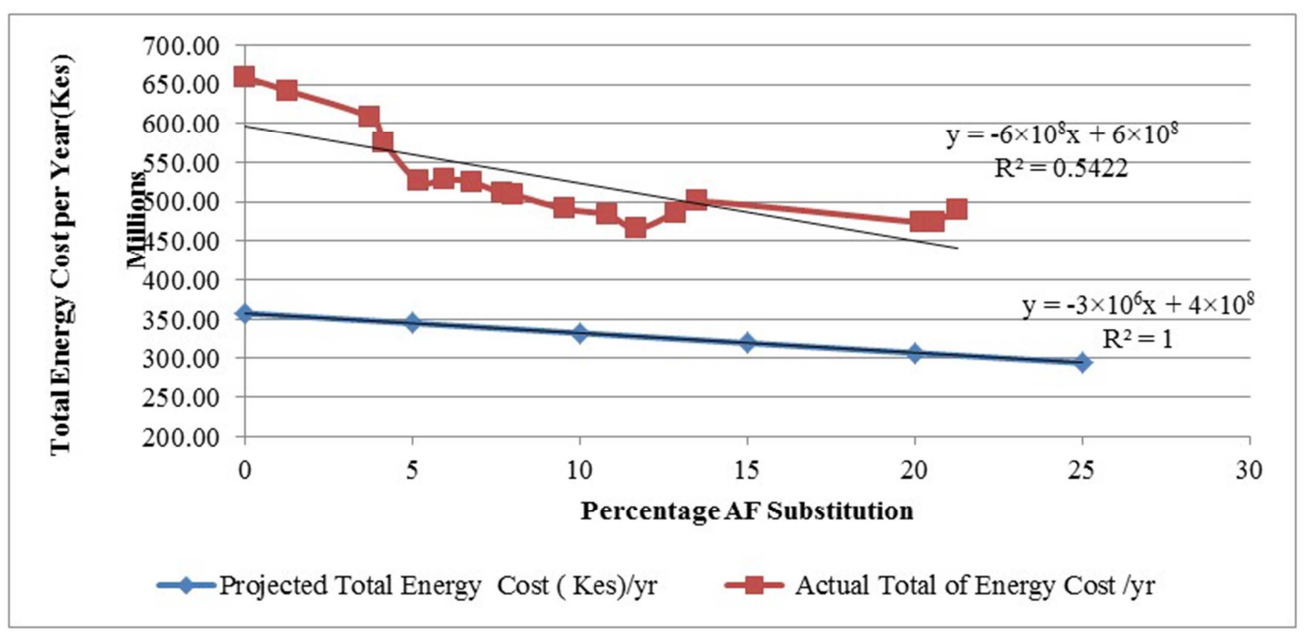

Figure 3. Projected and Actual Total Energy Cost per Year.

From the projected substitution scenario in table 1 and figure 3 the total energy cost was decreasing with an increase in AF substitution. This is because AF costs are lower than HFO and therefore energy mix cost cheaper than when only HFO is used. The relationship of total energy cost against percentage substitution is linear given by:

$$
y=-3 \times 10^{6} x+4 \times 10^{8}
$$

Where:

$\mathrm{y}=$ total cost of energy/year in Kenya shillings

$\mathrm{x}=$ percentage of $\mathrm{AF}$ substitution.

The above equation can be rewritten as:

$$
\text { Total energy cost } / \mathrm{yr}=-3 \times 10^{6} \% \mathrm{AF}+4 \times 10^{8}
$$

The degree of correlation of the total energy cost of energy and percentage AF substitution indicated by $R^{2}$ was 1 because this was an ideal scenario giving a perfect relation. On the other hand of actual substitution scenario the total energy cost per year was also decreasing with an increase in percentage AF substitution as shown in table 2 and figure 3. This was because the energy mix used was cheaper as opposed to using only HFO for drying. There was a fairly strong correlation of the total energy cost of energy and percentage AF substitution indicated by $R^{2}$ of 0.5422 . The curve was also not smooth because of technical errors during the operation of the dryer. The equation of the trend line of the total cost of energy against percentage AF substitution was linear given by: 


$$
y=-6 \times 10^{8} x+6 \times 10^{8}
$$

This implied that:

$$
\text { Total energy cost } / \mathrm{yr}=-6 \times 10^{8} \% \mathrm{AF}+6 \times 10^{8}
$$

From the experimental results the actual total energy costs were higher than the projected total energy cost.

\subsection{Projected and Actual HFO Cost per Year}

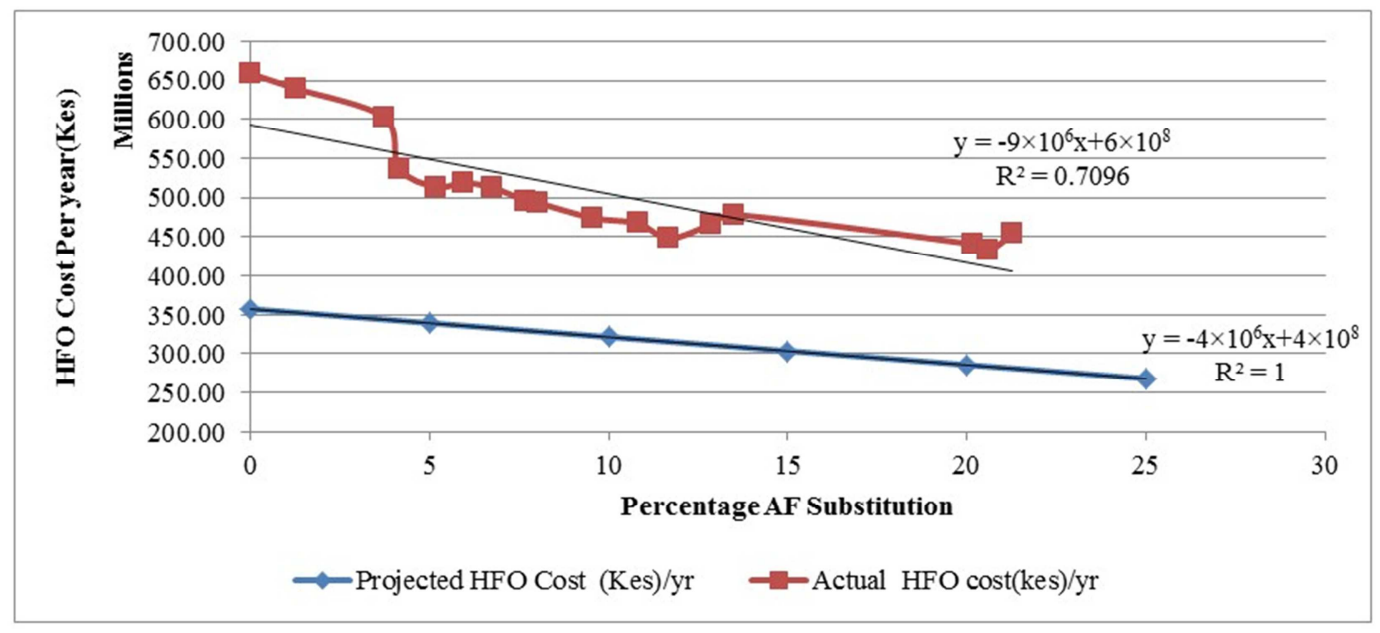

Figure 4. Projected and Actual HFO Cost per Year.

A comparison of projected HFO cost per year was done against actual HFO cost per year. From table 1 and figure 4 the cost of HFO was decreasing with an increase in percentage AF substitution in both projected and actual substitution scenarios. The relationship for the projected substitution scenario was expressed as:

$$
y=-4 \times 10^{6} x+4 \times 10^{8}
$$

Equation 5 can be rewritten as:

$$
\mathrm{HFO} \operatorname{cost} / \mathrm{yr}=-4 \times 10^{6} \% \mathrm{AF}+4 \times 10^{8}
$$

The correlation coefficient of $\mathrm{R}^{2}=1$ because this situation was a perfect scenario. The cost of HFO cost was decreasing because the cost of the energy mix was lower than the cost of using HFO only in the dryer.
From table 2 and figure 4, the actual cost of HFO was decreasing with an increase in percentage substitution. There was a fairly strong linear corellation between the cost of HFO and percentage AF substitution with $\mathrm{R}^{2}$ of 0.7096 . The curve of cost of HFO per year against percentage substitution was however not smooth because the scenario was real and therefore affected by the operating conditions. The equation for the trendline of the relationship between actual cost of HFO and percentage substitution was given by:

$$
y=-9 \times 10^{6} x+6 \times 10^{8}
$$

Equation 7 was rewritten as;

$$
\mathrm{HFO} \operatorname{cost} / \mathrm{yr}=-9 \times 10^{6} \% \mathrm{AF}+6 \times 10^{8}
$$

\subsection{Projected and Actual AF Cost}

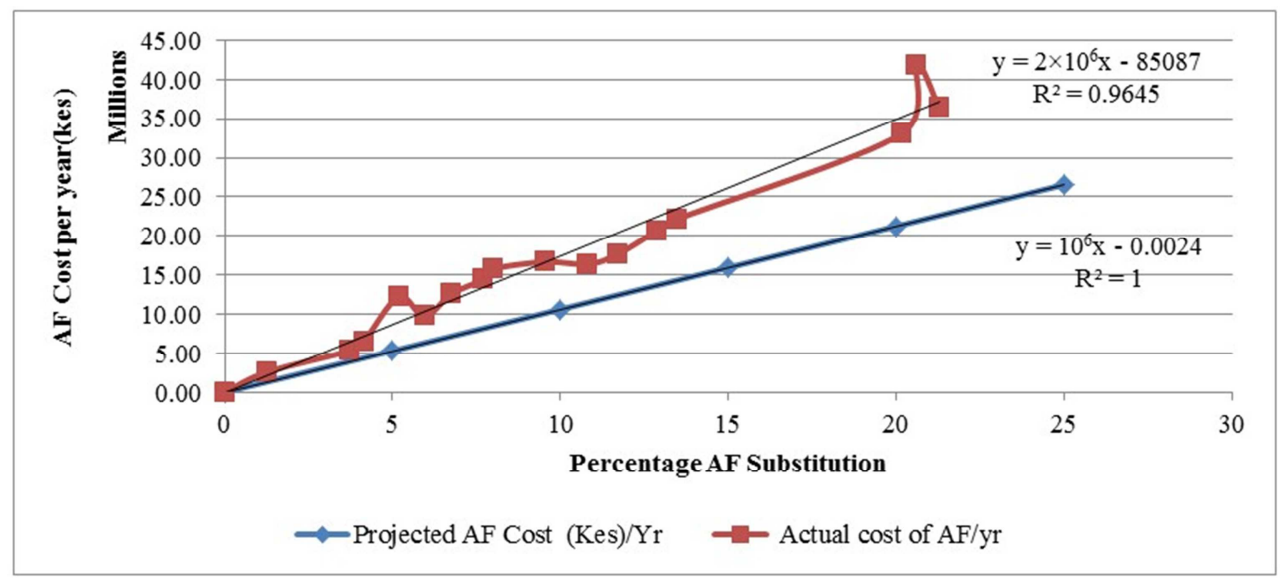

Figure 5. Projected and Actual AF Cost per Year.

For the projected substitution scenario from table 1 and figure 5, the cost of $\mathrm{AF}$ was increasing with an increase in percentage AF substitution. The relationship was expressed as: 


$$
y=1 \times 10^{6} x-0.0024
$$

This would further be expressed as:

$$
\mathrm{AF} \operatorname{cost} / \mathrm{yr}=1 \times 10^{6} \% \mathrm{AF}-0.0024 .
$$

The coefficient of correlation $\mathrm{R}^{2}$ was 1 because the scenario was ideal. The slope graph was increasing because more $\mathrm{AF}$ fuel was used as the percentage $\mathrm{AF}$ substitution increased.

From Table 2 and figure 5, the actual cost of AF per year was increasing with an increase in percentage $\mathrm{AF}$ substitution. This is because more AF was used with increasing percentage substitution. From figure 4.5 , there was a strong linear correlation between actual cost of $\mathrm{AF}$ and percentage AF substitution with $\mathrm{R}^{2}=0.9645$. However the curve was not smooth because substitution was real and therefore affected by the operating conditions of the system. The relationship of the actual substitution was expressed by a linear trend line of:

$$
y=2 \times 10^{6} x-85087
$$

This equation can further be expressed as:

$$
\mathrm{AF} \operatorname{cost} / \mathrm{yr}=2 \times 10^{6} \% \mathrm{AF}-85087
$$

\subsection{Projected and Actual Savings per Year}

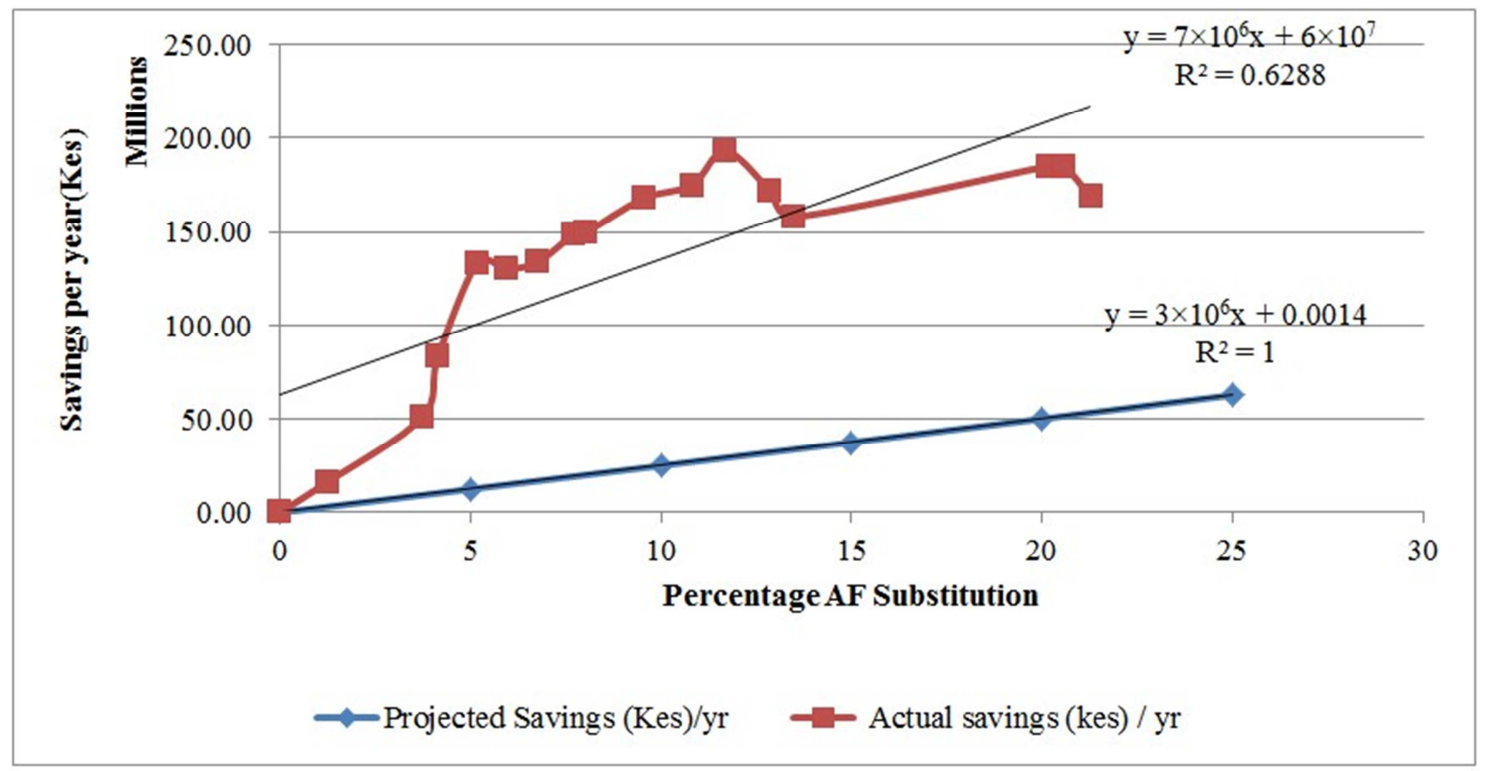

Figure 6. Projected and Actual Savings per Year.

In the projected substitution from table 1 and figure 6 , the percentage savings were increasing with an increase in percentage AF substitution. There was a linear relationship between percentage savings and percentage AF substitution expressed as:

$$
y=3 \times 10^{6} x+0.0014
$$

This implied that:

$$
\text { Savings }=3 \times 10^{6} \% \mathrm{AF}+0.0014
$$

The coefficient of correlation of $\mathrm{R}^{2}=1$ because the scenario was ideal. More savings were made with an increase in percentage $\mathrm{AF}$ substitution because the energy mix was cheaper than using HFO only for drying. For the actual substitution scenario from table 2 and figure 6 the costs savings per year increased with an increase in percentage substitution. This was because of the lower cost of the energy mix from HFO and AF. There was also fairly strong correlation of percentage savings and percentage $\mathrm{AF}$ substitution with $\mathrm{R}^{2}=0.6288$. The curve was not smooth because the substitution experiment was a trial and we experienced technical problems such as clogging of hopper with rice husks. There was a linear trade line relationship between the percentage savings and percentage $\mathrm{AF}$ substitution given by:

$$
y=7 \times 10^{6} x+6 \times 10^{7}
$$

This implied that:

$$
\text { Savings }=7 \times 10^{6} \% \mathrm{AF}+6 \times 10^{7}
$$

\subsection{Economic Analysis}

\subsubsection{Cost Benefit Analysis}

The cost of installing the pilot project was as indicated in table 3.

Table 3. Installation Cost Breakdown.

\begin{tabular}{ll}
\hline Cost Breakdown & Amount(KES) \\
\hline Steel structures material cost & $372,000.00$ \\
Mechanical/Electrical installation & $469,918.00$ \\
Materials cost(blower/electrical motor/rotary & $2,469,200.00$ \\
feeder/electrical cables/ panels \& automation) & $494,970.00$ \\
Trials(Labour \& rice husks) & $3,806,088.00$ \\
TOTAL & \\
\hline
\end{tabular}


Table 4. Fuel Handling Cost.

\begin{tabular}{llllll}
\hline Rice husks & $\begin{array}{l}\text { Monthly } \\
\text { tonnage }\end{array}$ & $\begin{array}{l}\text { Cost per ton } \\
\text { (KES) }\end{array}$ & $\begin{array}{l}\text { Transport cost/t to collection } \\
\text { center,(KES) }\end{array}$ & $\begin{array}{l}\text { Bagging, Handling } \\
\text { cost/t, (KES) }\end{array}$ & $\begin{array}{l}\text { Total cost per } \\
\text { ton,(KES) }\end{array}$ \\
\hline & 200 & 6000 & 800 & 1500 & 8300 \\
Total fuel handling cost & & & & & 1660000 \\
\hline
\end{tabular}

The maintenance cost was assumed to be at $5 \%$ in the first and second year, doubling in the third year and three times in the fourth and fifth year of the initial maintenance cost. The discounting rate was at $10 \%$.

Table 5. Cost Benefit Analysis.

\begin{tabular}{|c|c|c|c|c|c|}
\hline $\begin{array}{ll}\text { COSTS } & \text { YEAR } \\
\end{array}$ & 1 & 2 & 3 & 4 & 5 \\
\hline Installation costs & $3,806,088.00$ & 0.00 & 0.00 & 0.00 & 0.00 \\
\hline maintenance cost & $190,304.00$ & $190,304.00$ & $380,608.00$ & $570,912.00$ & $570,912.00$ \\
\hline fuel handling cost & $1,660,000.00$ & $1,660,000.00$ & $1,660,000.00$ & $1,660,000.00$ & $1,660,000.00$ \\
\hline Total cost per year & $5,656,392.00$ & $1,850,304.00$ & $2,040,608.00$ & $2,230,912.00$ & $2,230,912.00$ \\
\hline \multicolumn{6}{|l|}{ Benefits } \\
\hline Fuel cost Reduction & 0.00 & $25,122,151.63$ & $25,122,151.63$ & $25,122,151.63$ & $25,122,151.63$ \\
\hline Net Cash flow & $-5,656,392.00$ & $23,271,847.63$ & $23,081,543.63$ & $22,891,239.63$ & $22,891,239.63$ \\
\hline Discount rate & $10 \%$ & & & & \\
\hline Discount factors & 1.00 & 0.91 & 0.83 & 0.75 & 0.68 \\
\hline \multicolumn{6}{|l|}{ Discounted cash flows } \\
\hline Total cost per year & $5,656,392.00$ & $1,683,776.64$ & $1,693,704.64$ & $1,673,184.00$ & $1,517,020.16$ \\
\hline Benefits per year & 0.00 & $22,861,157.98$ & $20,851,385.85$ & $18,841,613.72$ & $17,083,063.11$ \\
\hline Net cash flow & $-5,656,392.00$ & $21,177,381.34$ & $19,157,681.21$ & $17,168,429.72$ & $15,566,042.95$ \\
\hline Cumulative & $-5,656,392.00$ & $15,520,989.34$ & $34,678,670.56$ & $51,847,100.28$ & $67,413,143.23$ \\
\hline NPV & KES $67,409,040.84$ & & & & \\
\hline IRR & 4.10 & & & & \\
\hline
\end{tabular}

This analysis was done to come up with the total costs incurred in the projects and the benefits to be gained from the implementation of the project to establish if the substitution was worthwhile. The analysis was done at a $10 \%$ alternative fuel substitution. Net present value and internal rate of return were calculated in order to take into account the time value of money. This was done using the excel program. NPV is normally calculated as:

$$
N P V=I_{1}+\frac{I_{2}}{1+r}+\frac{I_{3}}{(1+r)^{2}}+\cdots+\frac{I_{n}}{(1+r)^{n}}
$$

Where I's= cash flow for each year

The subscript $=$ year number

$r=$ the discount rate.

The internal rate of return is the interest rate that makes the Net Present Value zero.

$$
\begin{gathered}
0=P_{0}+\frac{P_{1}}{1+I R R}+\frac{P_{2}}{(1+I R R)^{2}} \\
+P_{3} /(1+I R R)^{3}+\ldots+P_{n} /(1+I R R)^{n}
\end{gathered}
$$

Where;

$\mathrm{P}_{0}, \mathrm{P}_{1}, \mathrm{P}_{2}, \mathrm{P}_{3} \ldots \mathrm{P}_{\mathrm{n}}$ is the cash flows in periods $1,2,3 \ldots \mathrm{n}$, respectively; and IRR is the project's internal rate of return. But from the excel function NPV was calculated as;

$$
N P V=N P V(\text { rate }, \text { value } 1, \text { value } 2, \ldots)
$$

And

IRR $=$ IRR (Net cash flow at year 1 : Net cash flow at year $5,0.1)(20)$

The cash flows were discounted at 10 percent in order to cater for the risks associated with the project. From the analysis a positive net present value of $67,409,040.84$ was realised which was an indicator that the substitution was worthwhile. IRR was calculated to be $4.10 \%$. This was the discount rate often that made the net present value of all cash flows from the substitution project equal to zero. The internal rate of return was a rate quantity which was an indicator of the efficiency, quality and yield of an investment.

\subsubsection{Effect of Substitution}

Projected substitution data was used to establish the effect of substitution. A graph of total energy cost and cost of using HFO only were plotted against \% AF substitution to establish the effect of substitution. 
Table 6. Substitution Effect.

\begin{tabular}{|c|c|c|c|c|c|c|c|c|c|c|c|}
\hline DESCRIPTION & $0 \%$ & $5 \%$ & $10 \%$ & $15 \%$ & $20 \%$ & $25 \%$ & $30 \%$ & $35 \%$ & $40 \%$ & $45 \%$ & $50 \%$ \\
\hline & 35749149 & 33961691 & 32174234 & 30386776 & 28599319 & 26811861 & 25024404 & 23236946 & 21449489 & 19662032 & 17874574 \\
\hline HFU Cost (Kes) & 1.33 & 6.77 & 2.20 & 7.63 & 3.07 & 8.50 & 3.93 & 9.37 & 4.80 & 0.23 & 5.67 \\
\hline AF Cost (Kes) & 0.00 & $\begin{array}{l}5313498.7 \\
5\end{array}$ & $\begin{array}{l}10626997 . \\
50\end{array}$ & $\begin{array}{l}15940496 . \\
25\end{array}$ & $\begin{array}{l}21253995 . \\
01\end{array}$ & $\begin{array}{l}26567493 . \\
76\end{array}$ & $\begin{array}{l}31880992 . \\
51\end{array}$ & $\begin{array}{l}37194491 . \\
26\end{array}$ & $\begin{array}{l}42507990 . \\
01\end{array}$ & $\begin{array}{l}47821488 . \\
76\end{array}$ & $\begin{array}{l}53134987 . \\
51\end{array}$ \\
\hline & 35749149 & 34493041 & 33236933 & 31980826 & 30724718 & 29468611 & 28212503 & 26956396 & 25700288 & 24444180 & 23188073 \\
\hline lotal Cost ( Kes) & 1.33 & 5.52 & 9.70 & 3.89 & 8.07 & 2.26 & 6.44 & 0.63 & 4.81 & 9.00 & 3.18 \\
\hline Savings (Kes) & 0.00 & $\begin{array}{l}12561075 . \\
82\end{array}$ & $\begin{array}{l}25122151 . \\
63\end{array}$ & $\begin{array}{l}37683227 . \\
45\end{array}$ & $\begin{array}{l}50244303 . \\
26\end{array}$ & $\begin{array}{l}62805379 . \\
08\end{array}$ & $\begin{array}{l}75366454 . \\
89\end{array}$ & $\begin{array}{l}87927530 . \\
71\end{array}$ & $\begin{array}{l}10048860 \\
6.52\end{array}$ & $\begin{array}{l}11304968 \\
2.34\end{array}$ & $\begin{array}{l}12561075 \\
8.15\end{array}$ \\
\hline
\end{tabular}

\begin{tabular}{|c|c|c|c|c|c|c|c|c|c|c|}
\hline DESC & $55 \%$ & $60 \%$ & $65 \%$ & $70 \%$ & $75 \%$ & $80 \%$ & $85 \%$ & $90 \%$ & $95 \%$ & $100 \%$ \\
\hline HFO Cost (Kes) & $\begin{array}{l}160871171 . \\
10\end{array}$ & $\begin{array}{l}142996596 . \\
53\end{array}$ & $\begin{array}{l}125122021 . \\
97\end{array}$ & $\begin{array}{l}107247447 . \\
40\end{array}$ & $\begin{array}{l}89372872 \\
3\end{array}$ & $\begin{array}{l}71498298.2 \\
7\end{array}$ & $\begin{array}{l}53623723 \\
0\end{array}$ & & $\begin{array}{l}17874574.5 \\
7\end{array}$ & 0.00 \\
\hline AF Cost (Kes) & $\begin{array}{l}58448486.2 \\
6\end{array}$ & $\begin{array}{l}63761985.0 \\
2\end{array}$ & $\begin{array}{l}69075483.7 \\
7\end{array}$ & $\begin{array}{l}74388982.5 \\
2\end{array}$ & $\begin{array}{l}79702481.2 \\
7\end{array}$ & $\begin{array}{l}85015980.0 \\
2\end{array}$ & $\begin{array}{l}90329478.7 \\
7\end{array}$ & $\begin{array}{l}95642977.5 \\
2\end{array}$ & $\begin{array}{l}100956476 . \\
27\end{array}$ & $\begin{array}{l}106269975 . \\
03\end{array}$ \\
\hline Total Cost ( Kes) & $\begin{array}{l}219319657 . \\
36\end{array}$ & $\begin{array}{l}206758581 . \\
55\end{array}$ & $\begin{array}{l}194197505 . \\
73\end{array}$ & $\begin{array}{l}181636429 . \\
92\end{array}$ & $\begin{array}{l}169075354 . \\
10\end{array}$ & $\begin{array}{l}156514278 \\
29\end{array}$ & $\begin{array}{l}143953202 . \\
47\end{array}$ & $\begin{array}{l}131392126 . \\
66\end{array}$ & $\begin{array}{l}118831050 . \\
84\end{array}$ & $\begin{array}{l}106269975 . \\
03\end{array}$ \\
\hline Savings (Kes) & 138171834 & 150732910 & 163293986 & 175855061 & 188416137 & 200977213 & 213538289 & 226099365 & 238660440 & 251221516 \\
\hline
\end{tabular}

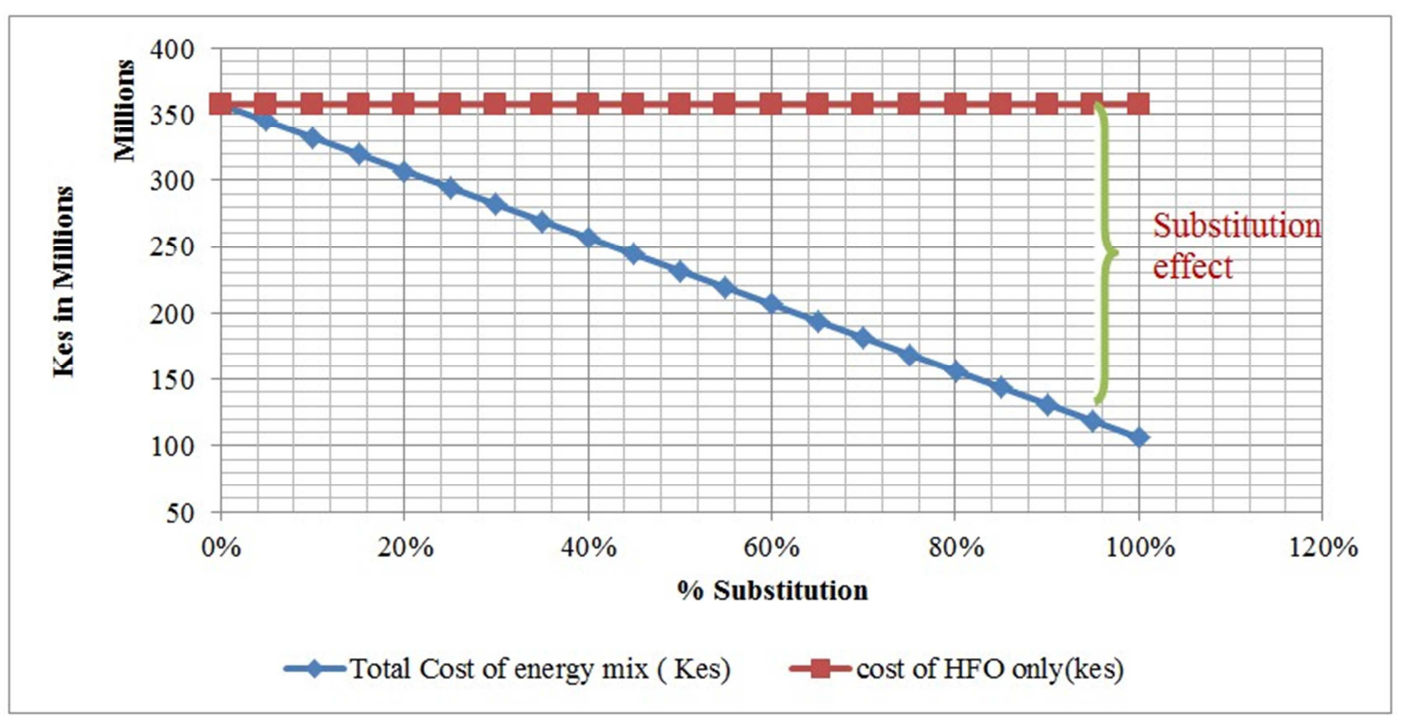

Figure 7. Substitution Effect.

The substitution effect measures how much higher price encourages consumers to use other goods, assuming the same level of income. Table 6 Figure 7 show a gradual cost drop of the energy used to dry pozzolana from 357,491,491.33 Kenya shillings with increasing percentage AF substituted to 106,269,975.03 Kenya shillings when HFO is completely substituted by AF. This effect is caused by the relatively high cost of HFO that induces the use of more of a relatively lower priced energy, that is, AF and less on high priced HFO. This is due the rise the cost of fossil fuels. This is a positive scenario in economics, but the degree of substitution can only be justified by the availability of $\mathrm{AF}$ to completely substitute $\mathrm{HFO}$ and the efficiency of the dryer to run on AF alone. This is an area for further research to determine the efficiency of the dryer in relation to the percentage substitution with HFO.

\subsubsection{Operational Expenditure Analysis}

Both simple payback period and return on investment were carried out to determine the viability of the investment. The analysis was carried out using the pilot substitution scenario with annual savings at $9.55 \% \mathrm{AF}$ fuel substitution.

Table 7. Operational Expenditure.

\begin{tabular}{lr}
\hline Pilot substitution project & \\
\hline Capital invested & \\
Installation costs & $3,806,088.00$ \\
fuel handling cost & $1,660,000.00$ \\
Total cost per year & $5,466,088.00$ \\
Annual savings at $10 \%=168000000$ (From table 2) \\
\hline
\end{tabular}

$$
\begin{gathered}
\text { Simple payback period }=\frac{\text { capital invested }}{\text { annual savings }} \\
=\frac{5466088}{168000000}=0.0325 \text { years }=0.39 \text { months }=12 \text { days }
\end{gathered}
$$




$$
\begin{gathered}
\text { ROI }=\frac{\text { Gain from investment }- \text { cost of investment }}{\text { cost of investment }} \\
\frac{168000000-5466088}{5466088}=29.72 \%
\end{gathered}
$$

From the operational expenditure analysis simple payback period was 12 days and return on investment was $29.72 \%$. The short payback period and high return on investment indicate that this project is of high yielding benefit to the investor. From the four capital budgeting techniques i.e. NPV, IRR, Simple payback period and ROI the investment was worthwhile to undertake.

\section{Conclusion}

From the findings reported in this study regarding the substitution of HFO with biomass in a pozzolana dryer, it can be concluded that Substitution led to a reduction of the cost of energy used and therefore savings increased with the increase of percentage substitution. Secondly, using the four techniques of capital budgeting, i.e. NPV, IRR, Simple payback period and ROI the investment was worthwhile to undertake. Researchers need to investigate further and determine the efficiency of the dryer in relation to the percentage substitution with HFO to determine the maximum efficiency. Future research can expand on substitution in relation on capital and labour employed and establish the percent savings per unit of cement produced.

\section{Nomenclature}

$\begin{array}{ll}€ & \text { Euro } \\ \mathrm{AF} & \text { Alternative Fuel } \\ \mathrm{CO} & \text { Carbon Monoxide } \\ \mathrm{CO}_{2} & \text { Carbon Dioxide } \\ \mathrm{GHG} & \text { Green House Gas } \\ \mathrm{GJ} & \text { Giga Joule }\end{array}$

$\begin{array}{ll}\text { HFO } & \text { Heavy Fuel Oil } \\ \mathrm{HGG} & \text { Hot Gas Generator } \\ \mathrm{kWH} & \text { Kilowatt Hour } \\ \mathrm{MJ} & \text { Mega Joule } \\ \mathrm{NGP} & \text { Nairobi Grinding Plant } \\ \mathrm{NO}_{\mathrm{x}} & \text { Nitrogen Oxides }\end{array}$

\section{References}

[1] Alsop, P. (2001). Cement plant operations handbook for dry process plants. $3^{\text {rd }}$ Edition, Trade ship Publications Ltd, Portsmouth, United Kingdom.

[2] Bamburi cement (2012), Annual Report and Financial Statements, Bamburi Cement Corporate Office Nairobi.

[3] Boden T.A, Marland.G, and Andres R.J. (2010), Global, Regional, and National Fossil-Fuel $\mathrm{CO}_{2}$ Emissions, Carbon Dioxide Information Analysis Centre, Oak Ridge National Laboratory, U.S. Department of Energy, Oak Ridge, Tenn., U.S.A. doi 10.3334/CDIAC/00001_V2010.

[4] Hendriks (1998), Reduction of Greenhouse Gases from the Cement Industry. Conference Proceedings, Switzerland.

[5] http://www.ucsusa.org/clean_energy/our-energy-choices/coaland-other-fossil-fuels/the-hidden-cost-of-fossil.html (accessed 21.09.13)

[6] Kurchania A.K. Rathore N.S., Panwar N.L (2006), Renewable Energy Theory \& Practice, Himanshu Publications.

[7] MIT Research Profile Letter, (2011), Clinker Grinding at Breaking Point, Concrete Sustainability Hub, 2011.

[8] NGP (2013), Bamburi Annual Report and Financial Statements.

[9] NGP (20112), Bamburi Annual Report and Financial Statements.

[10] United Nations Development Programme, (2009).Biomass Energy for Cement Production: Opportunities in Ethiopia. 